\title{
Recent increased incidences of potato late blight on the Jos Plateau: A case for intercropping
}

\author{
Chuwang Pam Zang \\ Department of Crop Science, Faculty of Agriculture, University of Abuja, Nigeria
}

\section{Email address:}

pamleechuwang@yahoo.com,pzchuwang@gmail.com

\section{To cite this article:}

Chuwang Pam Zang. Recent Increased Incidences of Potato Late Blight on the Jos Plateau: A Case for Intercropping. Agriculture, Forestry and Fisheries. Vol. 3, No. 5, 2014, pp. 363-367. doi: 10.11648/j.aff.20140305.15

\begin{abstract}
Potato cultivation on the Jos Plateau is a multi-Billion Naira enterprise which is on the very brink of collapse due to upsurge in the incidences and severity of late blight a disease caused by Phytophtora infestans (Mont) DeBary. This paper highlighted the scope of the spread of this scourge by assessing the magnitude of loses due to the disease in four zones of the potato growing region of the Jos Plateau- Bokkos, Ampang, Heipang and Vwang. The production parameters studied were the land area under potato, average yield, proportion of potato produced through sole/mono cropping, severity of the late blight epidemic and the level of adaptation of the new varieties imported from Europe the Americas and Australia. The results revealed that Bokkos was the most important potato growing area in terms of total land area, adoption of new planting materials, and sole/mono cropping system of production. The incidences and severity of the potato late blight was most serious in Bokkos, followed by Ampang, Heipang and Vwang in that order. The average yield of potato tubers (kg/ha) was highest in Ampang and least in Heipang. A brief view of the weather reports from these areas shows erratic patterns of rainfall and rise in temperature which may be attributed to the general climate change. A major trend observed in the weather report is the increase in early rainfall (March-April) which farmers tend to explore for early planting with severe consequences. The increasing tendency to adopt mono cropping by out growers for the multinational seed and other Agro-based companies was highlighted and the attendant risks involved while making a case for mixed/inter cropping. Other benefits suggested for inter cropping were higher resource use efficiencies, security against total crop lost, reduction in the use of pesticides to control diseases and pests as well as favorable environmental effects like shading, erosion control and suppressing weeds.
\end{abstract}

Keywords: Intercropping, Sole Cropping, Mono Cropping, Resource Use Efficiencies, Climate Change, Potato Late Blight, Incidence, Severity

\section{Introduction}

The colonial tin miners introduced Potato (Solanum tuberosum.L) on the Jos Plateau in the early $19^{\text {th }}$ Century to provide food for their European expatriate population (WPA, 2006). Since then the crop had become an integral part of the farming system of the local farmers who are responsible for producing over 1,500,000 metric tons and 92\% of Nigeria's annual output (Okwonkwo et al, 1995; FAO, 2012, NRCRI annual Reports, 2010). The rainy season crop which accounts for $82 \%$ of Nigeria's total annual production is prone to various diseases, the most economically important being late and early blights caused majorly by Phytophtora infestans (Mont) DeBary and Alterania solani respectively. These, by no means, are the only pathogens but they are the most important.
The incidences of blight have always been observed but the severity and frequency of the cases had never really exceeded the economic threshold to the extent which warranted the drastic control measures that were taken in the past few rainy seasons (2012, 2013 and 2014). This disturbing development predisposes the entire population of the Jos Plateau to food insecurity, economic deterioration and environmental pollution. The assertion is justified when we consider the fact that the potato crop, which is usually harvested early, holds the key to bridging the hunger gap during the critical period between July and August (Chuwang et al, 2007). Similarly the Potato business in Nigeria is conservatively estimated to be worth 300 Billion Naira (FAO, 2012, NRCRI, 2012) and the demand for fresh tubers had never been fully met. This potato demand deficit, in Nigeria, can only be effectively supplied from the Jos Plateau given 
the favorable climatic conditions like cool temperature due to high altitude.

Most of the potato produced $(70 \%)$ on the Jos Plateau is through intercropping with tropical cereals like maize, sorghum and millet by the small scaled farmers (Okonkwo, et al, 1995). However the most predominant crop mixture seems to be potato/maize considering the wide spread cultivation. The advantages of maize/potato intercropping was highlighted to include security against total crop yield, diversity of nutrition options, environmental management, higher nitrogen use efficiency, higher land/ other resources use efficiencies, creating artificial/physical barriers for pests and diseases (Allard, 1961, Chuwang, 2006, Bouws and Finckh, 2007, Chuwang and Odion, 2008).

However in recent times there appears to be a concerted effort by some key players in the potato industry of Nigeria most especially multinational seed companies, agro based/potato processing companies and some scientists to encourage mono cropping to the detriment of intercropping. The reasons usually advanced for this paradigm shift is that mono cropping provides the platform for easy mechanization and use of agro chemical (Gregor and Author, 1994). Other reasons include the production of clean and attractive tubers for 'seed' and for the market as well as reported apparent high levels of returns on investment with sole cropping (Chuwang, 2010). Plausible as this argument may seem, but the fact remains, that the threat of total crop lost and insecurity arising from it is as real as ever. This was demonstrated by the disaster of the 2014 Blight epidemic where thousands of hectares of potato farms were devastated by the scourge.

The object of this paper is to make a case for intercropping potato with a non- host crop species like maize or other cereal in order to forestall or contain the emerging threat posed by potato late blight and other diseases.

\section{Materials and Methods}

\subsection{The Study Area}

The potato producing areas of the Jos Plateau $\left(9^{0} 6^{1}-10.5^{0}\right.$ $\left.\mathrm{N} ; 8^{0} 35^{1} \mathrm{~W}-9^{0} 45^{1} \mathrm{~W}\right)$ were divided into four segments for the purpose of this investigation. These sectors or areas are

- Bokkos/Nbar/Kuba with all the adorning areas

- Ampang/ Kerang with all the adorning areas

- Vwang/Kuru/Miango with all the adorning areas

- Heipang/Kassa with all the adorning areas

\subsection{Weather Reports}

The weather report for the entire Jos Plateau was collated for analysis from the Potato Program of the National Root Crop Research Institute in Kuru. The information mostly accessed was rainfall distribution and duration as well as maximum and minimum temperature. Where it is available the record of relative humidity is analyzed for the past 5-10 years.

A summary of these elements of the weather is made to assess the trends of changes as may be observed in the years under consideration along with data from global climate change websites and other similar sources. These summaries and analyzed data are presented in figures.

\subsection{Farm Visits, Interviews and Discussions with Potato Farmers and other Stake Holders}

Five farms were visited from each of the potato growing areas and the farmers were interviewed. Farmers from contiguous farms were engaged in discussions to obtain information on the increase in incidences of late blight and other problems of production as well as farming system options open to them. These interactions and visits yielded data on average potato tuber yield, total land area and the types and sources of planting materials as well as farming/production system adopted. The late blight incidence and severity levels as well as their economic implications were dully evaluated on the farmers' fields.

\subsection{Review of Reports of Potato Late Blight on the Jos Plateau}

The reports available were analyzed and compared with what really took place on the field. These reports included among others the field reports of the Plateau Agricultural Development Programme (PADP), the NRCRI- Potato programme Kuru, the Plateau state Ministry of Agriculture and the Agric units of the affected local governments, namely Barkin-Ladi, Bokkos, Mangu, Jos South, Riyom and Bassa.

\subsection{Data Analysis}

Simple percentages were calculated and the chart were prepared with the help of Micro-Soft Excel 2010 Version

\section{Results}

The result is presented area by area and all the parameters studied are displayed in figures 1 to 4 .

\subsection{Bokkos Area}

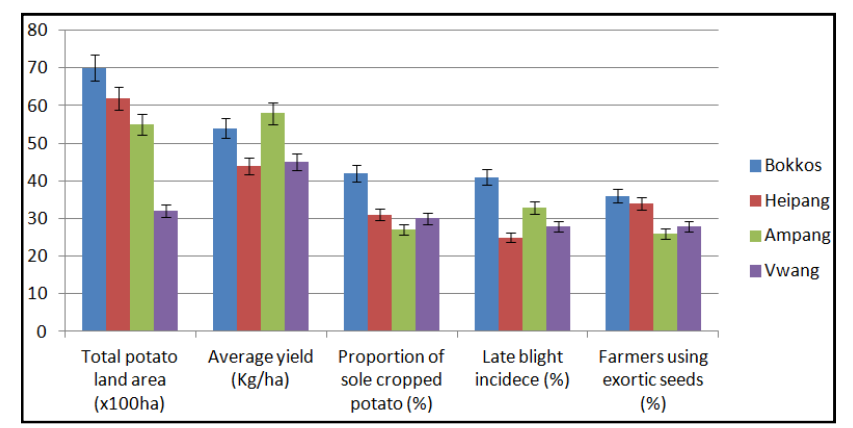

Figure 1. Potato Production Information for the four farming centers on the Jos Plateau (2014). 


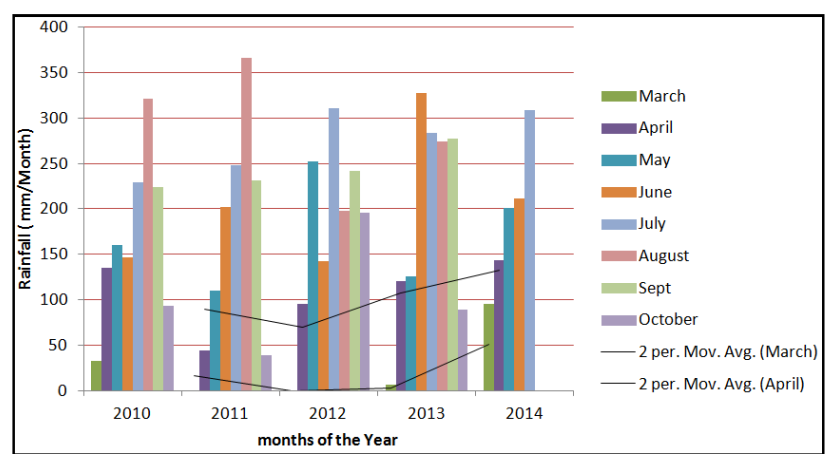

Figure 2. Rainfall Distribution on the Jos Plateau (2010-2014).

The result of the survey presented in figure 1 shows that the Bokkos area had the largest land area committed to potato and the second highest unit yield per hectare when compared to the other areas. However the potato farmers in Bokkos seemed to have accepted mono cropping much more readily than the other areas because the proportion of potato produced through monocropping there was highest. Most of the farmers that used newly introduced potato varieties from Europe America and Australia were found in the Bokkos area. The earliest and most serious cases of late blight were also reported from this potato growing area.

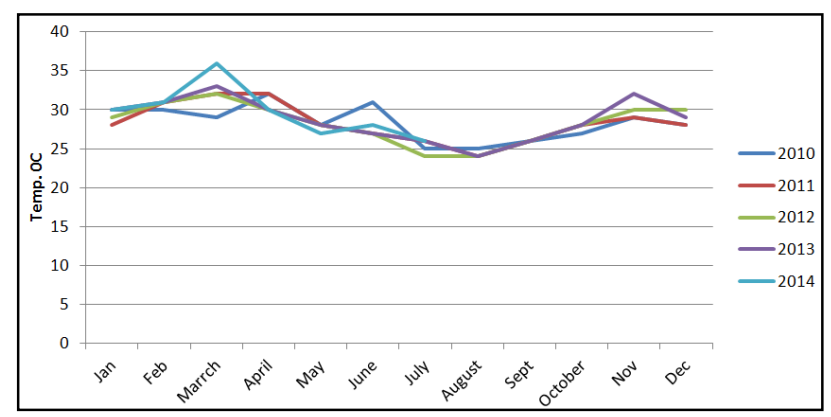

Figure 3. Average Maximum Temperature on the Jos Plateau (2010-2014).

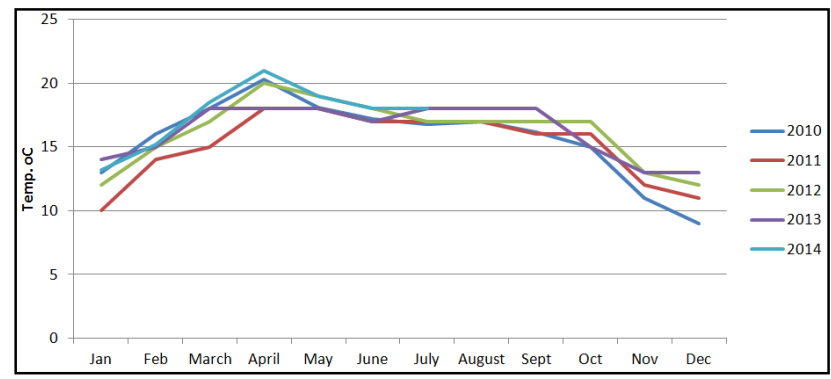

Figure 4. Average Minimum Temperature ( ${ }^{\circ}$ ) On the Jos Plateau (20102014).

\subsection{Ampang/Kerang}

In this area produced the highest yield of potato per unit area of land in the entire state and also has the lowest proportion of potato farmers using new varieties introduced from the western world as well as the smallest quantity of tubers produced through sole cropping. The reported incidences of late blight were serious but not as serious as in the Bokkos area.

\subsection{Heipang/Kassa Area}

The total land area dedicated to potato in the Heipang/Kassa area is the second largest in the state but the yield per unit area is less than in both Bokkos and Ampang. The newly introduced varieties had been as fairly well accepted as in Bokkos. Intercropping here as in Vwang and Ampang are still very heavily practiced in view of the low proportion of potato produced as sole crops and the reported incidences of late blight were not as serious as in Bokkos and Ampang.

\subsection{Vwang/Miango}

All the parameters studied in this area had the least values. However the differences between these values and those obtained at Heipang were not very appreciable.

\subsection{Weather Report}

The weather data assessed were total rainfall, average minimum and maximum temperature from 2010 to 2014 . The records revealed unusual rainfall patterns such as the heavy rainfall early in the year which coincided with unusually high temperatures. (figs 2and3). The average minimum temperature which is usually a fare reflection of night temperatures have remained within the range which allows for effective tuberization by the crop plants but in 2014 there was an upsurge which tends to exceed the $20^{\circ} \mathrm{C}$ mark (fig 4).

\section{Discussion}

Most of the potato produced in Ampang/Kerang comes from the foothill of (and the area around) the fertile Kerang volcanic hill which is rich in volcanic ash hence the relatively high yields. The area, like Bokkos, is also located on the very edge of the Jos Plateau characterized by deep gorges and misty weather. This misty weather may have been responsible for the relatively high incidences and equally high severity of the reported late blight of potato. Another probable factor that was responsible for these severe incidences of blight in these two areas was the heavy monsoon-like rainfall which came very early in the season most especially between late March and April of 2014. Heavy rainfall had been reported to be a major factor in accelerating the incidence and severity of potato late blight most especially in the tropical highlands (Hijmans et al, 2000). In Bokkos, like in some parts of Ampang, the farmers usually cultivate the potato crop with the earliest rainfall usually between early and middle of April). This year (2014) very heavy rainfall was recorded between March and May which also coincided with a period of unusually high temperature (fig 2 and 3 ). This situation resulted in the potato blight outbreak early in the growing season before the commencement of full tuberization by the crop plants, hence the outcome was very devastating for the farmers in these areas.

Recently (within the last two or three years), new varieties of potato planting materials have been imported from Europe, 
the Americas, and Australia by multinational and indigenous companies of Nigeria. These new planting materials may not have adapted very well to the tropical conditions and most probably do not possess any degree of tolerance to the blight pathogens available on the Jos Plateau. More over with global rise in temperature and unpredictable rainfall patterns due to climate change, it is very likely that the blight tolerance capacity of the indigenous potato varieties may have been greatly compromised as there exist reports of this from other places (Hijmans, et al, 2000, Forbes and Simons, 2007, Shankar, 2014). The most serious incidences of potato late blight reported are from areas that have a relatively higher level of adoption of these new varieties. Bokkos and areas surrounding it have the highest adoption rate as a result the potato plants grown may have been very susceptible to the pathogens. In the Bokkos area, where the epidermic was most severe (DailyTrust,2014), a comparatively large proportion of the potato farmers practice sole cropping than in other areas, where the disease was not as severe. Growing of potato along with a non-host crop plant species had been reported to reduce the spread of the Potato late blight pathogens significantly (Bouws and Finckh, 2008). Intercropping potato with maize or other cereals like sorghum will not only present the potential to check the spread of blight on the potato plants but also to guard against total yield lost as was the case in some farms where the disease started very early in the season prior to commencement of tuberization. This pest and disease control advantage of intercropping potato with maize or other nonblight host crop species makes it environment friendly due to reduced usage of environment harmful pesticides.

Previously over $90 \%$ of all the potato produced in Nigeria was from intercropping (Okwonko et al., 1995). However, in recent years, seed companies, who engage most of the prominent potato farmers as out growers, have tended to discourage them from practicing their traditional farming system which is based predominantly on intercropping potato with cereals like maize and some legumes such as Phaseolus spp. With the current Nigerian government transformation of the Agricultural sector of the economy, which encourages private sector investment, more seed companies and other Agro based/potato processing outfits will emerge to engage more out growers and consequently more potato farms lands will be committed to sole/mono cropping in the coming years. This emerging trend will diminish the natural benefits derivable from intercropping such as better pest/disease management, food security and wider dietary options as well as more efficient use of resources like land, labour, fertilizers and other agrochemicals (Gregor and Author, 1994, Bouws and Finckh, 2008). Apart from the pest/disease control benefits and enhanced resource use efficiencies, intercropping is more in tone with nature as the intercropped field seeks to mimic the natural undisturbed or uncultivated fields where variety of life forms coexist in harmony. These harmonious interrelationships could have beneficial effects for the components of the ecosystem as in legume/grass intercrops where the grass benefits from the $\mathrm{N}$-fixing activities of the legumes. These ideas and the role of the taller plant species (maize/sorghum) in shading the shorter potato to lower the soil temperature for more effective tuberization had been reported (Harris, 1990, Chuwang, 2006,). The environmental impacts of these and other observed benefits opens room for further research.

The consequences of climate change like the erratic rainfall patterns experienced early in 2014 and general increase in air temperature are most likely to continue for some time (Climate Change Reports, 2007, Bindi, 2007). The trend line (figure 2) of rainfall of March and April shows a steady increase that is also most likely to persist for some time to come. The implication of this on a tropical location like the Jos Plateau may manifest in obscure and uncertain growing seasons as well as an upsurge in pests and disease incidences (Hijmans, et al, 2000 ,Sparks et al, 2014).

\section{Conclusion}

With newly introduced, untested and disease susceptible planting materials in circulation as well as the emergence of more sole cropping production practices coupled with unpredictable weather conditions, occasioned by climate change, it is pertinent to consider the tested and time honored traditional practices like intercropping which provides the assurance against total crop failure and ensures more efficient utilization of resources.

\section{References}

[1] Allard, R.W. (1961) Relationship between genetic diversity and consistency of performance in different environments. Crop Science 1: 127-133

[2] Bindi, M.(2007) How climate change affects potato crops. Forth assessment report of climate Change report of the Intergovernmental Panel on Climate Change (IPCC), 2007

[3] Bouws, H and Finckh, M.R. (2008) The effect of strip intercropping of potato with non-hosts On late blight severity and tuber yield in organic agriculture. Plant Pathology Vol 57 (5) $916-927$

[4] Chuwang, P. Z. (2006) Productivity of Potato-Maize intercrop as Influenced by $\mathrm{N}$ levels and Planting Arrangement. Ph.D dissertation submitted to the Post graduate school of the Ahmadu Bello University (A.B.U.) Zaria, March 2006.

[5] Chuwang, P.Z., Odion, E.C. and Aliyu, L, (2007)The response of potato and maize yields to $\mathrm{N}$ fertilizer and planting pattern in Jos, Plateau state of Nigeria. Journal of League of Researchers in Nigeria (JOLORN) Vol 8 (2) 22-30

[6] Chuwang, P.Z. (2010) Maize/Potato intercrop as influenced byN levels and planting patterns On the Plateau savanna of Kuru, Jos, Nigeria ACTA Agronomica Nigeriana Vol. 19 (2) 22-30

[7] Chuwang, P.Z. and Odion, E.C.(2010) Nitrogen Use Efficiency of potato/ maize intercrop as Affected by $\mathrm{N}$ levels and arrangement in a mid- altitude location of Jos Nigeria. Agriculture Business and Technology Journal Vol 8 (2) 144155. ISSN 2007-0807 
[8] Climate change (2007) Synthesis Report of the Intergovernmental Panel on Climate change (IPCC) xxvii (Valencia Spain $12^{\text {th }}-17^{\text {th }}$ Nov., 2007

[9] Daily Trust (2014) Newspaper report with caption Nigeria: Disease ravages over 500 hectares of Irish potato farms in Plateau State. $29^{\text {th }}$ May 2014

[10] FAOSTAT (2012) The Food and Agriculture Organization production statistics for 2012 Forbes,G.A. and Simon, R. (2007) Implication for a warmer, wetter world on the late pathogen: How CIP efforts can reduce risk foe low input potato farmers. International Potato Cente, Apartodo 1558 Lima, Peru Icrisat ejournal, 2007.

[11] Gregor, P. and Author, RM. (1994) Monocropping, intercropping or crop rotation? An economic case study of west African Guinea Savanna with special reference to risk. Agricultural Systems 45(1994): 123-143

[12] Harris, PM. (1990) Potato crop radiation use: A justification for intercropping. Field Crops Research 25: 25-39
[13] Hijmans, RF., Forbes, GA. and Walker,TS (2000) Estimating the global severity of potato late blight with GIS- linked disease forecast models. Plant Pathology Vol 42 (6) 697-705

[14] NRCRI (2012) The annual Potato Programme Report of the National Root Crops Research Institute, Umidike (2012).

[15] Okwonko, JC., Ene, LSO. and Okoli, OO(1995) Potato Production in Nigeria. NCRCI, Umudike, Nigeria.

[16] Shankar, KS (2014) Understanding the threat of potato late blight under climate change from Ecuador to Nepal. International Potato Center (IPC). Agricultural Research for development Newsletter.

[17] Sparks, A.H.,Forbes, G.A.,Hijmans, R.J. and Garrett, K. A, (2014) Climate change effects on the global risk of potato late blight gisweb.ciat.cgiar.org/RTB Maps/Docs potato late blight also at onlinelibrary.wiley.com/doi/10.1111/gcb.12587.

[18] WPA (2006) World Potato Atlas: Africa-Archives, country chapter, Nigeria. Edited by Kelly Theisen of CIP Lima Peru. 